The publisher gratefully acknowledges the generous support of the Humanities Endowment Fund of the University of California Press Foundation. 
The Life of Cheese 


\section{CALIFORNIA STUDIES IN FOOD AND CULTURE}

Darra Goldstein, Editor 


\title{
The Life of Cheese
}

Crafting Food and Value in America

\author{
Heather Paxson
}

尼

UNIVERSITY OF CALIFORNIA PRESS

Berkeley Los Angeles London 
University of California Press, one of the most distinguished university presses in the United States, enriches lives around the world by advancing scholarship in the humanities, social sciences, and natural sciences. Its activities are supported by the UC Press Foundation and by philanthropic contributions from individuals and institutions. For more information, visit www.ucpress.edu.

University of California Press

Berkeley and Los Angeles, California

University of California Press, Ltd.

London, England

() 2013 by The Regents of the University of California

Library of Congress Cataloging-in-Publication Data

Paxson, Heather, 1968-

The life of cheese : crafting food and value in America / Heather Paxson.

p. cm. - (California studies in food and culture; v. 41)

Includes bibliographical references and index.

ISBN 978-0-520-27017-6 (cloth : alk. paper) — ISBN 978-0-520-27018-3 (pbk. : alk. paper)

1. Cheesemaking-United States. 2. Cheese industry-United States. 3. Cheese-Social aspects-United States. 4. Food habitsUnited States. 5. Local foods-United States. I. Title.

SF274.U6P39 2013

$637^{\prime} \cdot 3-\mathrm{dc} 23$

2012026487

Manufactured in the United States of America

$\begin{array}{llllllllll}22 & 21 & 20 & 19 & 18 & 17 & 16 & 15 & 14 & 13\end{array}$

$\begin{array}{llllllllll}10 & 9 & 8 & 7 & 6 & 5 & 4 & 3 & 2 & 1\end{array}$

In keeping with a commitment to support environmentally responsible and sustainable printing practices, UC Press has printed this book on Rolland Enviro10o, a 100\% post-consumer fiber paper that is FSC certified, deinked, processed chlorine-free, and manufactured with renewable biogas energy. It is acid-free and EcoLogo certified. 